\title{
Digestible tryptophan requirement for tambaqui (Colossoma macropomum) fingerlings ${ }^{1}$
}

\author{
Exigência de triptofano digestível para alevinos de tambaqui (Colossoma \\ macropoтum)
}

\author{
Marcos Antonio Delmondes Bomfim², Rafael Silva Marchão ${ }^{2 *}$, Felipe Barbosa Ribeiro², Jefferson Costa de \\ Siqueira ${ }^{2}$, Louis Ramos Silva ${ }^{2}$ and Sylvia Sanae Takishita ${ }^{3}$
}

\begin{abstract}
The objective of this study was to determine the digestible tryptophan requirement of tambaqui (Colossoma macropomum) fingerlings and its relationship with digestible lysine. A total of 300 tambaqui fingerlings with three initial weights $(2.12 \pm 1.19,8.13 \pm 0.75$, and $15.18 \pm 1.91 \mathrm{~g})$ were distributed in a randomized complete block design, consisting of six treatments $(0.225,0.256,0.288,0.319,0.350$, and $0.381 \%$ of digestible tryptophan) and five replicates of 10 fish per plot. The tryptophan to lysine ratio was estimated using a $1.78 \%$ level of digestible lysine. Variables regarding performance, food efficiency, and body deposition of protein, fat, and ashes, and nitrogen retention efficiency were evaluated. Feed intake and nitrogen retention efficiency did not vary. For the digestible tryptophan intake, feed conversion and body deposition of ashes, the model that best fit was the Linear Response Plateau, with these variables improving with the elevation of digestible tryptophan concentration up to the levels of $0.335,0.276$ and $0.259 \%$, respectively. Weight gain, specific growth rate, digestible tryptophan efficiency for weight gain, and body deposition of protein and fat increased in a quadratic manner with elevated digestible tryptophan levels; the estimated optimal levels were $0.320,0.310,0.280,0.323$ and $0.299 \%$, respectively. The recommended digestible tryptophan level in rations for tambaqui fingerlings is $0.323 \%$, corresponding to $0.108 \%$ /Mcal of digestible energy with a digestible tryptophan to lysine ratio of $18 \%$.
\end{abstract}

Key words: Essential amino acids. Corporal composition. Zootechnical performance. Amazon fish.

RESUMO - Objetivou-se determinar a exigência de triptofano digestível para alevinos de tambaqui (Colossoma macropomum) e sua relação com a lisina digestível. Foram utilizados 300 alevinos de tambaqui com três pesos iniciais $(2,12 \pm 1,19 ; 8,13$ $\pm 0,75$ e $15,18 \pm 1,91 \mathrm{~g})$ em delineamento em blocos ao acaso, composto por seis tratamentos $(0,225 ; 0,256 ; 0,288 ; 0,319$; 0,350 e $0,381 \%$ de triptofano digestível) e cinco repetições com dez peixes por parcela. A relação do triptofano com a lisina foi estimada utilizando como referência o nível de $1,78 \%$ de lisina digestível. Foram avaliadas variáveis de desempenho e eficiência alimentar, as deposições corporais de proteína, gordura e cinzas e a eficiência de retenção de nitrogênio dos peixes. O consumo de ração e a eficiência de retenção de nitrogênio não variaram. Para o consumo de triptofano digestível, conversão alimentar e deposição de cinzas, o modelo que melhor se ajustou foi o Linear Response Plateau, melhorando com a elevação da concentração de triptofano até os níveis de 0,$335 ; 0,276$ e $0,259 \%$, respectivamente. O ganho de peso, taxa de crescimento específico, eficiência de triptofano digestível para o ganho de peso e as deposições de proteína e gordura aumentaram de forma quadrática com a elevação dos níveis de triptofano, estimando os níveis ótimos de 0,$320 ; 0,310 ; 0,280$; 0,323 e $0,299 \%$, respectivamente. A recomendação do nível de triptofano digestível em rações para alevinos de tambaqui é de $0,323 \%$, correspondente a $0,108 \%$ / Mcal de energia digestível e relação do triptofano com a lisina digestível de $18 \%$.

Palavras-chave: Aminoácidos essenciais. Composição corporal. Desempenho zootécnico. Peixe amazônico.

\footnotetext{
DOI: $10.5935 / 1806-6690.20200025$

*Author for correspondence

Received for publication in 06/05/2019; approved in 12/11/2019

${ }^{1}$ Parte do trabalho de conclusão de curso do quinto autor, apresentado ao Curso de Zootecnia da Universidade Federal do Maranhão/UFMA

${ }^{2}$ Centro de Ciências Agrárias e Ambientais/CCAA, Universidade Federal do Maranhão/UFMA, Chapadinha-MA, Brasil, madbomfim@yahoo.com. br (ORCID ID 0000-0002-1707-2970), rafaelmarchao@yahoo.com.br (ORCID ID 0000-0003-4676-3452), felipebribeiro@yahoo.com (ORCID ID 0000-0002-2505-3964), jc.siqueira@ufma.br (ORCID ID 0000-0002-6692-0972), louis-ramos1 @ hotmail.com (ORCID ID 0000-0002-7858-5761)

${ }^{3}$ Faculdade de Tecnologia do Estado de São Paulo/FATEC, Jacareí-SP, Brasil, sanae.tk@ gmail.com (ORCID ID 0000-0001-8046-4531)
} 


\section{INTRODUCTION}

Brazilian fish farming is a productive activity that is growing in economic, social, and environmental importance. The productive potential of the sector has been emerging and reached 722,560 tons of farmed fish produced in 2018 (ASSOCIAÇÃO BRASILEIRA DE PISCICULTURA-PEIXE BR, 2019). In this context, the production of native species has grown significantly and provided important gains to the sector, especially in the economic context, but it is also of important social and environmental relevance. This is because of the production of species of familiar and regional knowledge of the Brazilian people, or as a way to resist the entry of exotic species into the country that may pose risks to native fish biodiversity (LATINI et al., 2016).

Among native cultivated species, tambaqui (Colossoma macropomum) is the species most produced by Brazilian fish farming. The species has the zootechnical advantages of great rusticity and high resistance to hypoxia, characteristics that favor its production in semi-intensive systems (dams, nurseries, and tanks), as well as in intensive systems (nurseries, aerated tanks, net tanks). For the successful breeding of this species, knowledge concerning various aspects related to its management is essential, highlighting the importance of a greater understanding of food management for the species (RODRIGUES, 2014).

In fish diets, protein is the most expensive nutritional component of feed and is required at high levels compared to feed for other non-ruminant animals. However, dietary protein can only be used efficiently when its amino acid composition meets the dietary requirements for maintenance and physiological activities for production (BOSCOLO et al., 2011; NATIONAL RESEARCH COUNCIL, 2011). This indicates that a feed formulated based solely on protein content may not guarantee all amino acids for nutritional needs, compromising fish performance because metabolically fish do not have a protein requirement but provided adequate protein can balance essential and nonessential amino acids (BOMFIM et al., 2010; CYRINO et al., 2010; FURUYA et al., 2013). In addition, at levels exceeding animal requirements, proteins increase nitrogen discharge into the environment, contributing to eutrophication of aquatic environments.

Among essential amino acids, tryptophan is of paramount importance because it is one of the limiting amino acids in alternative sources of fish meal (PEZZATO; BARROS; FURUYA, 2009; ZAMINHAN, et al., 2017). Supplementation in the fish diet improvements growth, feed conversion and growth rate (FARHAT; KHAN, 2014; ZAMINHAN et al., 2017, 2018), as well as reduces aggressiveness (HOSSEINI;
HOSEINI, 2013) and cannibalism in fingerlings (KRÓL; ZAKĘŚ, 2016). Tryptophan is a precursor to serotonin (5hydroxytryptamine neurotransmitter) and niacin (vitamin B3) and is one of the amino acids that stimulates insulin secretion and growth hormones. Thus, it is an important neurotransmitter that affects the physiological functions and behavioral responses of fish (BASIC et al., 2013; ROSSI; TIRAPEGUI, 2004). The objective of this study was to determine the requirement for digestible tryptophan and its relationship with digestible lysine for tambaqui (Colossoma macropomum) fingerlings.

\section{MATERIAL AND METHODS}

The experiment was conducted at the Aquatic Organism Food and Nutrition Laboratory, at the Center for Agricultural and Environmental Sciences of the Federal University of Maranhão (UFMA), located in ChapadinhaMA $\left(03^{\circ} 44^{\prime} 33^{\prime \prime} \mathrm{S}, 43^{\circ} 21^{\prime} 21^{\prime \prime} \mathrm{W}\right.$; altitude $\left.105 \mathrm{~m}\right)$, for 40 days, with 10 days for adaptation to the experimental conditions and 30 days for the experimental period. It was conducted in accordance with the ethical standards for animal use research, after approval by the Animal Use Ethics Committee of the Federal University of Maranhão (Protocol: 23115007623 / 2014-25).

A total of 300 pure tambaqui fingerlings, acquired from the National Department of Drought Works (DNOCS), located in Piripiri-PI, with three distinct initial weights $(2.12 \pm 1.19 ; 8.13 \pm 0.75$ and $15.18 \pm 1.91 \mathrm{~g})$ were distributed in a randomized block design consisting of six treatments (digestible tryptophan levels) and five replications, accounting for 30 experimental units with 10 fish each. For the formation of the blocks, the initial average weight of the fish was considered. Two repetitions were used for each treatment for the initial average weight of 2.12 and $8.13 \mathrm{~g}$ and only one repetition per treatment for the initial average weight of $15.18 \mathrm{~g}$.

Experimental diets were formulated using the "diet dilution" technique (FISHER; MORRIS, 1970). Two diets were used, one free of protein (FPD) based on cornstarch and soybean oil and another containing $0.381 \%$ tryptophan (reference diet) based on corn and soybean meal. The reference diet was formulated based on the ideal protein content with tryptophan as the only limiting amino acid, considering the recommended requirements for Nile tilapia by the National Research Council (2011) and the Brazilian Tilapia Nutrition Tables (FURUYA et al., 2010) (Table 1).

To obtain the experimental diets, the reference diet was sequentially diluted with the protein-free diet, resulting in isoenergic, isocalcic and isophosphoric diets, 
Table 1 - Composition of the protein-free (PFD) and reference (RD) diets (natural matter)

\begin{tabular}{crr}
\hline \multirow{2}{*}{ Ingredients (\%) } & \multicolumn{2}{c}{ Diets } \\
\cline { 2 - 3 } & PFD & \multicolumn{1}{c}{ RD } \\
\hline Soybean meal & 0.000 & 61.318 \\
Corn & 0.000 & 27.800 \\
Corn starch & 80.816 & 0.000 \\
Soybean oil & 10.154 & 4.174 \\
Rice husk & 4.029 & 0.000 \\
DL-Methionine (99.00\%) & 0.000 & 0.872 \\
L-Threonine (98.50\%) & 0.000 & 0.583 \\
L-Isoleucine (99.00\%) & 0.000 & 0.733 \\
Calcitic limestone & 0.059 & 0.166 \\
Dicalcium phosphate & 3.827 & 0.000 \\
Vitamin and mineral premix ${ }^{1}$ & 0.500 & 3.284 \\
Vitamin C & 0.050 & 0.500 \\
Salt & 0.545 & 0.050 \\
Antioxidant (BHT) & 0.020 & 0.020 \\
\hline
\end{tabular}

${ }^{1}$ Vitamin and mineral supplement $\left(5 \mathrm{~kg} \mathrm{t}^{-1}\right)$ with guaranteed levels per kilogram of product: Total vitamins, 1,200,000 IU; vit. D3, 200,000 IU; vit. E, 1,200 mg; vit. K3, 2,400 mg; vit. B1, 4,800 mg; vit. B2, 4,800 mg; vit. B6, 4,800 mg; vit. B12, 4,800 mg; folic acid, 1,200 mg; Ca pantothenate, $12,000 \mathrm{mg}$; vit. C, $48,000 \mathrm{mg}$; biotin, $48 \mathrm{mg}$; choline chloride, $108 \mathrm{~g}$; niacin, 24,000 mg; $\mathrm{Fe}, 50,000 \mathrm{mg}$; $\mathrm{Cu}, 3,000 \mathrm{mg}$; Mn, 20,000 mg; Zn, 30,000 mg; I, $100 \mathrm{mg}$; Co, $10 \mathrm{mg}$; Se, $100 \mathrm{mg}$; ${ }^{2}$ Vitamin C: Calcium L-ascorbic acid 2-monophosphate, $42 \%$ of active ingredients

containing $0.225,0.256,0.288,0.319,0.350$ and $0.381 \%$ digestible tryptophan (Table 2).

To estimate the digestible tryptophan to lysine ratio, $1.78 \%$ of digestible lysine as recommended by Silva et al. (2018) for tambaqui juvenile diets was used. The estimation was performed under similar experimental conditions (food management and environmental conditions), such that the results could be compared, as recommended by Lemme (2013).

The fish were kept in 30 polyethylene boxes (aquariums) with $500 \mathrm{~L}$ volumetric capacity in a closed water circulation system, with a supply system, supplementary aeration, and individual drainage. The water supply came from an artesian well. The boxes were cleaned daily by siphoning after measuring the water temperature.

The water temperature was measured daily at 7:30 and 17:30 $\mathrm{h}$ with the aid of a mercury bulb thermometer graduated from 0 to $50{ }^{\circ} \mathrm{C}$. Controls for $\mathrm{pH}$ and the content of dissolved oxygen and ammonia in the water were measured every seven days using a $\mathrm{pH}$ meter, oximeter and commercial kit for toxic ammonia test, respectively.

Experimental diets were pelleted. To minimize the possibility of ingredient leaching, they were provided daily in six meals (08:00, 10:00, 12:00, 14:00, 16:00 and 18:00 h). In each meal, small quantities were supplied with successive passages until apparent satiety for maximum intake.

At the beginning of the experiment, 50 fish were stunned and euthanized by benzocaine overdose (500 $\left.\mathrm{mg} \mathrm{L}^{-1}\right)$ and frozen. At the end of the experiment, after fasting $24 \mathrm{~h}$, all fish from boxes were collected, stunned and euthanized by benzocaine overdose $\left(500 \mathrm{mg} \mathrm{L}^{-1}\right)$. Then, the final fish biometrics and feed intake per experimental unit were measured. Fish samples (initial and final/experimental plot) were identified, oven-dried with forced air circulation, predegreased, ball milled and packed in laboratory analysis containers.

The carcasses were analyzed for body composition (moisture, protein and lipids) according to procedures described by Silva and Queiroz (2005) in the Animal Nutrition Laboratory of the Federal University of Maranhão - UFMA.

At the end of the experiment, the following performance and feed efficiency indexes were evaluated: feed intake (FI), digestible tryptophan intake (DTI), weight gain (WG), specific growth rate (SGR), feed conversion (FC), and efficiency of digestible tryptophan for weight gain (ETW). Performance parameters were calculated according to the following equations:

$F I(g)=$ feed consumed during the experimental periodh;

DTI $(\mathrm{mg})=[$ feed intake $(\mathrm{mg}) \times$ digestible tryptophan level in feed (\%)]/100;

$W G(g)=$ final mean weight $(g)$ - initial mean weight $(g)$;

SGR $\left(\%\right.$ day $\left.{ }^{-1}\right)=$ [(natural logarithm of final weight (g) - natural logarithm of initial weight $(g)) \times 100] /$ experimental period (days);

$F C\left(g g^{-1}\right)=$ feed intake $(g) /$ weight gain $(g)$;

ETW $\left(g g^{-1}\right)=$ weight gain $(g) /$ digestible tryptophan intake $(g)$.

The chemical composition of the fish (moisture, ash, protein and fat) was evaluated. Based on body composition, the daily deposition rates of body protein and fat (DPD and DFD, respectively), body ash deposition (DAD) and retention efficiency of nitrogen (NRE), according to the equations below: 
$D P D\left(m g d a y^{-1}\right)=\{[($ final body protein, $\% \times$ final weight, $m g)$ - (initial body protein, $\% \times$ initial weight, $m g$ )]/100\}/ experimental period (days);

DFD $\left(m g d a y^{-1}\right)=\{[($ final body fat, \% final weight, mg) - (initial body fat, \% × initial weight, mg)]/100\}/ experimental period (days);

$D A D\left(m g\right.$ day $\left.^{-1}\right)=\{[($ final body ash, $\% \times$ final weight, mg) - (initial body ash, \% × initial weight, mg)]/100\}/ experimental period (days);

$\operatorname{NRE}(\%)=[$ final body $N(\%) \times$ final weight $(g)]-$ [initial body $N(\%) \times$ initial weight $(g)] /($ feed intake, $g \times N$ level in ration, $\%) / 100$

The statistical analyses were conducted using the SAEG program, System of Statistical and Genetic Analysis, developed at the Federal University of Viçosa (2007). The data were interpreted using an analysis of variance. The effects of the digestible tryptophan levels in the diets were explored by decomposing the degrees of freedom of the digestible tryptophan levels using first and second order orthogonal polynomials $(p<0.05)$ based on the best fit. The adjustment was also verified for the Linear Response Plateau (LRP) model. To determine the best fitting model, the $P$ value (significance) and/or $\mathrm{R}^{2}$ (SQ of the model/SQ of the treatment) was taken into account.

\section{RESULTS AND DISCUSSION}

The water quality parameters remained within the recommended standards for the breeding of the species, as recommended by Mendonça et al. (2009). The maximum and minimum water temperatures remained around $27.08 \pm 0.50{ }^{\circ} \mathrm{C}$ and $24.79 \pm 0.88^{\circ} \mathrm{C}$, respectively. The dissolved oxygen concentration in the water was approximately $8.64 \pm 0.48 \mathrm{ppm}, \mathrm{pH}$ was $6.72 \pm 0.14$ and total ammonia $\leq 1.00 \mathrm{ppm}$.

There was no mortality during the experimental period. There was also no external pathological signs, even in animals fed diets deficient in digestible tryptophan levels.

Feed intake was not affected $(p>0.05)$ by the increase in digestible tryptophan levels (Table 3).

Table 2 - Chemical composition of the protein-free diet (PFD), reference (RD) and experimental diets elaborated by the "diet dilution" technique, based on the concept of ideal protein (natural matter)

\begin{tabular}{|c|c|c|c|c|c|c|c|}
\hline \multirow{2}{*}{ Diets $(\%)$} & \multirow{2}{*}{ PFD } & \multicolumn{6}{|c|}{ Tryptophan Digestible Level (\%) } \\
\hline & & 0.225 & 0.256 & 0.288 & 0.319 & 0.350 & 0.381 (DR) \\
\hline \multicolumn{8}{|c|}{ Dilution (\%) } \\
\hline PFD & 100.00 & 40.91 & 32.73 & 24.55 & 16.36 & 8.18 & 0.00 \\
\hline $\mathrm{RD}$ & 0.00 & 59.09 & 67.27 & 75.45 & 83.64 & 91.82 & 100.00 \\
\hline \multicolumn{8}{|c|}{ Calculated composition 1} \\
\hline Crude protein $(\%)$ & 0.00 & 18.73 & 21.33 & 23.92 & 26.51 & 29.11 & 31.70 \\
\hline Digestible protein $(\%)^{3}$ & 0.00 & 17.19 & 19.57 & 21.95 & 24.33 & 26.71 & 29.09 \\
\hline Digestible energy $(\mathrm{kcal} / \mathrm{kg})^{2,3}$ & 3.000 & 3.000 & 3.000 & 3.000 & 3.000 & 3.000 & 3.000 \\
\hline Ethereal extract (\%) & 10.20 & 7.93 & 7.59 & 7.24 & 6.90 & 6.55 & 6.21 \\
\hline Digestible lysine $(\%)^{2}$ & 0.000 & 1.300 & 1.480 & 1.660 & 1.840 & 2.020 & 2.200 \\
\hline Digestible met. + cys $(\%)^{2}$ & 0.000 & 0.819 & 0.932 & 1.046 & 1.159 & 1.273 & 1.386 \\
\hline Digestible threonine $(\%)^{2}$ & 0.000 & 1.040 & 1.184 & 1.328 & 1.472 & 1.616 & 1.760 \\
\hline Total tryptophan (\%) & 0.000 & 0.238 & 0.271 & 0.304 & 0.337 & 0.370 & 0.403 \\
\hline Digestible tryptophan $(\%)^{2}$ & 0.000 & 0.225 & 0.256 & 0.288 & 0.319 & 0.350 & 0.381 \\
\hline Digestible isoleucine $(\%)^{2}$ & 0.000 & 0.832 & 0.947 & 1.062 & 1.178 & 1.293 & 1.408 \\
\hline Digest. tryp./ energy (kcal/kg) & 0.000 & 0.075 & 0.085 & 0.096 & 0.106 & 0.117 & 0.127 \\
\hline Digest.tryp/ lysine ratio & 0.00 & 17.30 & 17.30 & 17.30 & 17.30 & 17.30 & 17.30 \\
\hline
\end{tabular}

Calculated composition: P available, 0.70\%; Ca total, 0.96\%; Na total, 0.22\%; Crude Fiber, 3.73\%; digestible met. + cyst./lysine ratio, 63\%; digestible threonine/lysine ratio, $80 \%$; digestible tryptophan/lysine ratio, $17 \%$; digestible isoleucine/lysine ratio, $64 \%$; ${ }^{1}$ Based on the values proposed by Rostagno et al. (2011); ${ }^{2}$ Based on the digestibility coefficients of industrial amino acids proposed by Rostagno et al. (2011) and for amino acids and P availability for corn and soybean meal and dicalcium phosphate proposed by Furuya (2010); ${ }^{3}$ Based on the digestibility coefficients for maize starch, maize, soybean meal and soybean oil proposed by Furuya et al. (2010) for Nile tilapia 
Table 3 - Feed intake (FI), digestible tryptophan intake (DTI), weight gain (WG), specific growth rate (SGR), feed conversion (FC), and efficiency of digestible tryptophan for weight gain (ETW) of tambaqui fingerlings and summary of the analysis of variance, according to the level of digestible tryptophan in the diet

\begin{tabular}{crrrrrr}
\hline \multirow{2}{*}{ Digestible tryptophan level $(\%)$} & \multicolumn{6}{c}{ Variable } \\
\cline { 2 - 7 } & FC $(\mathrm{g})$ & DTC $(\mathrm{mg})$ & WG $(\mathrm{g})$ & ${\text { SGR }\left(\% \text { day }^{-1}\right)}^{\text {FC }\left(\mathrm{g} \mathrm{g}^{-1}\right)}$ & ${\text { ETW }\left(\mathrm{g} \mathrm{g}^{-1}\right)}$ \\
\hline 0.225 & 23.38 & 55.67 & 18.17 & 4.35 & 2.07 & 280.56 \\
0.256 & 26.42 & 71.63 & 25.41 & 5.25 & 1.53 & 340.45 \\
0.288 & 26.04 & 79.18 & 30.28 & 5.87 & 1.35 & 376.29 \\
0.319 & 28.93 & 97.49 & 30.64 & 6.08 & 1.60 & 286.32 \\
0.350 & 26.64 & 98.56 & 27.81 & 5.39 & 1.65 & 241.20 \\
0.381 & 24.41 & 98.38 & 26.70 & 4.90 & 1.61 & 232.41 \\
Value P linear & 0.6470 & 0.0003 & 0.0806 & 0.2401 & 0.0223 & 0.0214 \\
Value P quadratic & 0.1133 & 0.1880 & 0.0248 & 0.0007 & 0.0002 & 0.0252 \\
Value de P LRP & 0.0776 & 0.0001 & 0.0023 & 0.0951 & 0.0091 & 0.5000 \\
CV (\%) & 19.26 & 22.86 & 27.53 & 14.01 & 10.99 & 22.97 \\
\hline
\end{tabular}

CV - Coefficient of variation (\%); LRP - Linear Response Plateau

Consequently, the energy intake and other nutrients consumed by fish did not vary. Only protein varied because it was the only nutritional component whose concentration differed among the diets.

Because the digestible tryptophan was the first limiting amino acid of the protein component in the experimental diets, the significant effects observed in the variables occurred in response to the difference in the digestible tryptophan intake, which increased in a linear manner $(\mathrm{p}<0.01)$ based on its concentration in the diet. Despite the linear variation, the LRP model was the best fit for the data and the estimated level of the amino acid was $0.335 \%$ at the plateau that occurred (Table 4 ).
The increase in digestible tryptophan levels influenced the weight gain $(\mathrm{p}<0.05)$ and the specific growth rate $(\mathrm{p}<0.01)$ of the fingerlings, which increased in a quadratic manner until the estimated digestible tryptophan levels of 0.320 and $0.310 \%$, respectively (Tables 3 and 4; Figure 1). The results show that the use of diets with levels of digestible tryptophan that did not meet the requirements of the fish was detrimental and limited body protein synthesis (NATIONAL RESEARCH COUNCIL, 2011; SILVA et al., 2018) and decreased weight gain and specific growth rate.

The results confirmed the essentiality of tryptophan for tambaqui fingerlings. This was likewise observed in

Table 4 - Adjusted regression equations, determination coefficients and requirement values for digestible tryptophan intake (DTI), weight gain (WG), specific growth rate (SGR), feed conversion (FC), and efficiency of digestible tryptophan for weight gain (ETW) of tambaqui fingerlings, according to the level of digestible tryptophan in the diet

\begin{tabular}{ccccc}
\hline Variable & Model & Equation & $\mathrm{R}^{2}$ & Requirement $(\%)$ \\
\hline DTI $(\mathrm{mg})$ & Linear & $\hat{\mathrm{Y}}=-3.305+286.275 \mathrm{x}$ & 0.88 & - \\
DTI $(\mathrm{mg})$ & LRP & $\hat{\mathrm{Y}}=98.142-372.448(0.335-\mathrm{x})$ & 0.98 & 0.335 \\
WG $(\mathrm{g})$ & Quadratic & $\hat{\mathrm{Y}}=-105.728+851.708 \mathrm{x}-1329.534 \mathrm{x}^{2}$ & 0.95 & 0,320 \\
WG $(\mathrm{g})$ & LRP & $\hat{\mathrm{Y}}=28.384-192.083(0.276-\mathrm{x})$ & 0.89 & 0.276 \\
SRG $\left(\%\right.$ day $\left.^{-1}\right)$ & Quadratic & $\hat{\mathrm{Y}}=-15.493+138.378 \mathrm{x}-223.250 \mathrm{x}^{2}$ & 0.96 & 0.310 \\
FC $\left(\mathrm{g} \mathrm{g}^{-1}\right)$ & Linear & $\hat{\mathrm{Y}}=2.099-1.531 \mathrm{x}$ & 0.14 & - \\
FC $\left(\mathrm{g} \mathrm{g}^{-1}\right)$ & Quadratic & $\hat{\mathrm{Y}}=7.687-39.602 \mathrm{x}+62.837 \mathrm{x}^{2}$ & 0.64 & 0.315 \\
FC $\left(\mathrm{g} \mathrm{g}^{-1}\right)$ & LRP & $\hat{\mathrm{Y}}=1.620+11.312(0.259-\mathrm{x})$ & 0.79 & 0.259 \\
ETW $\left(\mathrm{g} \mathrm{g}^{-1}\right)$ & Linear & $\hat{\mathrm{Y}}=-572.819+466.532 \mathrm{x}$ & 0.36 & - \\
ETW $\left(\mathrm{g} \mathrm{g}^{-1}\right)$ & Quadratic & $\hat{\mathrm{Y}}=-629.775+6896.538 \mathrm{x}-12328.203 \mathrm{x}^{2}$ & 0.70 & 0.280 \\
\hline
\end{tabular}


Figure 1 - Weight gain of tambaqui fingerlings as a function of digestible tryptophan levels in the diet

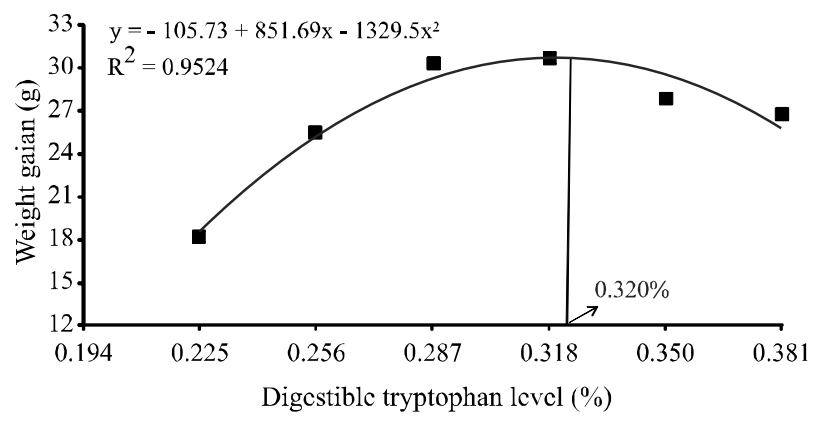

research conducted on Nile tilapia (Oreochromis niloticus) by Nguyen et al. (2019) and Zaminn et al. (2017, 2018), and catfish (Rhamdia quelen) by Pianesso et al. (2015).

There was a significant effect of treatments on the feed conversion $(\mathrm{p}<0.01)$, which improved in response to increments of digestible tryptophan in the diets up to the estimated level of $0.259 \%$ of the amino acid, after which a plateau occurred according to the best model data adjustment, LRP. There was also an effect of the treatments on the efficiency of digestible tryptophan on weight gain that varied in a quadratic manner $(\mathrm{p}<0.05)$, increasing to the level of $0.280 \%$ of the amino acid (Tables 3 and 4).

Because the conditions of feed and energy intakes were similar among treatments, the improvement in feed conversion and the efficiency of digestible tryptophan for weight gain occurred because of the improvement in the amino acid balance and corroborated the results of weight gain and specific growth rate. There was greater efficiency in the use of the protein fraction for lean tissue formation because it is more energetically efficient than fat deposition (BOMFIM et al., 2010; SILVA et al., 2018).

Considering the scarcity of data regarding the digestible tryptophan levels recommended for tambaquis, the comparison of the observed results with the results of studies Nile tilapia, a tropical and omnivorous species, was adopted. Thus, the digestible tryptophan levels estimated to optimize the weight gain $(0.320 \%)$ and specific growth rate $(0.310 \%)$ of tambaqui fingerlings were similar to the levels of $0.300 \%$ and $0.310 \%$ obtained in studies conducted by Zaminn et al. (2018), on fry (3.4 to $19.5 \mathrm{~g}$ ) and by Nguyen et al. (2019) on juvenile (7.9 to $77.5 \mathrm{~g}$ ) Nile tilapia. However, the results were slightly higher than the level of $0.290 \%$ estimated by Zeguin et al. (2017) who studied juvenile (38.2 to $132.6 \mathrm{~g}$ ) tilapia.

The differences observed in the tryptophan requirements may be related to the species, energy level of the rations, water temperature, weight range of the fish, and the statistical model used to estimate the requirements. In addition, the deficiency of another essential amino acid in the experimental diets (second limiting amino acid) may have limited protein synthesis at the highest levels of tryptophan tested, and consequently, underestimated the values of the levels obtained (BOMFIM et al., 2010; PIANESSO et al., 2015; NATIONAL RESEARCH COUNCIL, 2011; SILVA et al., 2018; SIQUEIRA et al., 2009).

Metabolic rates of growth vary among different fish species. The species that have the genetic potential to express higher growth rates are those that have higher requirements for digestible amino acids. Similarly, the fish life stages that have been involved in different studies is another factor that could explain the differences observed. Younger fish (larvae and fingerlings) have higher growth rates than fish in the growing and finishing stages, which implies differences in amino acid requirement values between the different breeding phases (TAKISHITA et al., 2009).

The increase in digestive tryptophan in the diets effected the daily body deposition of protein and fat, which varied in a quadratic manner $(\mathrm{p}<0.05$ and $\mathrm{p}<0.01$, respectively), implying an increase in deposition up to the estimated digestible tryptophan levels of 0.323 and $0.299 \%$, respectively (Tables 5 and 6, and Figure 2).

The increase in daily body deposition of protein confirmed the observed results of the performance and feed efficiency variables, and demonstrated that the supply of adequate digestible tryptophan levels in the diet favored lean tissue formation by increasing the efficiency of food use and conversion into muscle protein. Performance maximization occurred up to the level of $0.323 \%(0.108 \%$ digestible tryptophan Mcal from $\mathrm{ED}^{-1}$ ). Simultaneously, the best balance of amino acids caused an increase in the efficiency of energy and mineral retention because the intake of diet, and consequently, digestible energy and minerals were similar among treatments (BOMFIM et al., 2010; PIANESSO et al., 2015). On the other hand, the increase in energy expenditure to catabolize excess amino acids in fish at higher levels of digestible tryptophan, and consequently, protein, reduced the amount of liquid energy available for deposition of body fat (BOMFIM et al., 2010; ZEHRA; KHAN, 2014). These effects are similar to those observed in tambaqui by Silva et al. (2018).

The daily body deposition of ash exhibited a linear increase $(p<0.05)$ because of the increase in the dietary concentration of digestible tryptophan (Table 5). Despite the linear variation, the best fit model for the data was the LRP ( $\mathrm{p}<0.01$ ), demonstrating that there was an increase in this variable up to $0.276 \%$ of digestible tryptophan at which a plateau occurred (Table 6). The linear increase 
Table 5 - Body deposition of protein (DPD), fat (DFD), and ash (DAD), and nitrogen retention efficiency (NRE) of tambaqui fingerlings, according to the level of digestible tryptophan in the diet

\begin{tabular}{ccccc}
\hline \multirow{2}{*}{ Digestible tryptophan Level $(\%)$} & \multicolumn{4}{c}{ Variable } \\
\cline { 2 - 5 } & DPD $\left(\mathrm{mg} \mathrm{day}^{-1}\right)$ & DFD $\left(\mathrm{mg} \mathrm{day}^{-1}\right)$ & DAD $\left(\mathrm{mg} \mathrm{day}^{-1}\right)$ & NRE $(\%)$ \\
\hline 0.225 & 58.66 & 58.95 & 11.01 & 34.49 \\
0.256 & 81.47 & 74.58 & 15.03 & 41.52 \\
0.288 & 115.39 & 89.67 & 21.17 & 48.81 \\
0.319 & 97.72 & 77.71 & 18.97 & 34.78 \\
0.350 & 91.64 & 63.39 & 17.74 & 30.07 \\
0.381 & 96.08 & 61.21 & 20.04 & 31.41 \\
Value P linear & 0.0546 & 0.5699 & 0.0468 & 0.1350 \\
Value P quadratic & 0.0293 & 0.0046 & 0.1646 & 0.1039 \\
Value P LRP & 0.3450 & 0.1931 & 0.0022 & 0.5000 \\
CV (\%) & 29.03 & 22.31 & 37.18 & 29.70 \\
\hline
\end{tabular}

CV - Coefficient of variation; LRP - Linear Response Plateau

Table 6 - Adjusted regression equations, determination coefficients and requirement values for the variables body deposition of protein (DPD), fat (DFD), and body ash (DAD) of tambaqui fingerlings and summary of the analysis of variance, according to the digestible tryptophan level in the diet

\begin{tabular}{ccccc}
\hline Variable & Model & Equation & $\mathrm{R}^{2}$ & Requirement (\%) \\
\hline DPD $\left(\mathrm{mg} \mathrm{day}^{-1}\right)$ & Quadratic & $\hat{\mathrm{Y}}=-376.920+2986.360 \mathrm{x}-4625.462 \mathrm{x}^{2}$ & 0.74 & 0.323 \\
DFD $\left(\mathrm{mg} \mathrm{day}^{-1}\right)$ & Quadratic & $\hat{\mathrm{Y}}=-258.105+2274.270 \mathrm{x}-3804.146 \mathrm{x}^{2}$ & 0.75 & 0.299 \\
DAD $\left(\mathrm{mg} \mathrm{day}^{-1}\right)$ & Linear & $\hat{\mathrm{Y}}=3.109+46.902 \mathrm{x}$ & 0.53 & - \\
DAD $\left(\mathrm{mg} \mathrm{day}^{-1}\right)$ & LRP & $\hat{\mathrm{Y}}=-18.917-161.603(0.276-\mathrm{x})$ & 0.89 & 0.276 \\
\hline
\end{tabular}

Figure 2 - Graphical representation of protein and body fat deposition for tambaqui fingerlings, as a function of digestible tryptophan levels in the diet

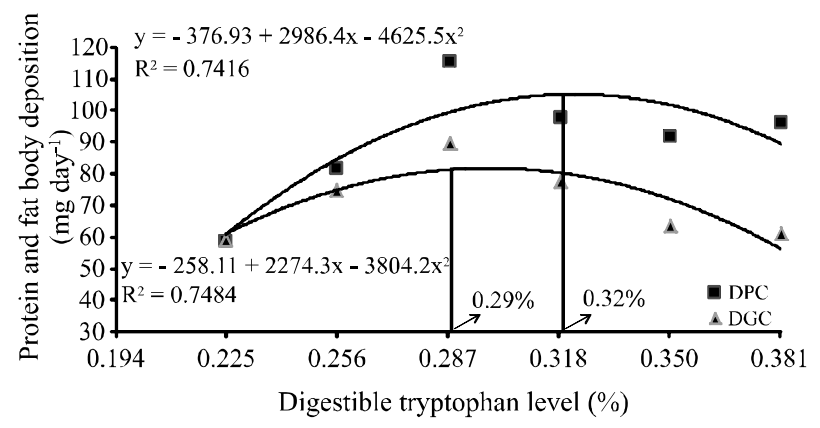

in ash deposition in response to the increase in digestible tryptophan content in diets may be related to the formation of bone tissue to support muscle tissue (SOUSA et al., 2018).

Regarding the nitrogen retention efficiency, there was no adjustment $(p>0.05)$ for any of the regression models evaluated. It was expected that there would be an improvement in nitrogen retention with the increase in the levels of tryptophan, considering that the increase in the consumption of digestible tryptophan/crude protein would cause an increase in the proportion of ingested amino acids, which could result in protein deposition processes in relation to maintenance. At excess levels, the proportion of amino acids destined for catabolism is increased, decreasing the percentage of nitrogen retained (BOMFIM et al., 2010).

Considering that the increase in dietary digestible tryptophan levels to the estimated level of $0.323 \%$ increased the deposition of body protein and the requirement for digestible lysine of $1.78 \%$ (Silva et al., 2018), the minimum ratio of tryptophan levels with digestible lysine is $18 \%$.

\section{CONCLUSION}

The recommendation for the digestible tryptophan level in the diet of tambaqui fingerlings is $0.323 \%(0.108 \%$ 
Mcal of $\mathrm{ED}^{-1}$ ), corresponding to a digestible tryptophan to lysine ratio of $18 \%$, to provide greater protein body deposition.

\section{ACKNOWLEDGMENTS}

Centro de Ciência Agrárias e Ambientais da Universidade Federal do Maranhão-CCAA-UFMA, for the availability of the infrastructure to carry out the experiment.

Fundação de Amparo à Pesquisa e ao Desenvolvimento Científico e Tecnológico do Maranhão - FAPEMA, for granting a scientific initiation scholarship during the experiment.

\section{REFERENCES}

ASSOCIAÇÃO BRASILEIRA DE PISCICULTURA-PEIXE BR. Tambaqui de cultivo, produção e consumo em crescimento no país. Anuário 2018. Disponível em: https://www.peixebr. com.br/anuario2018/. Acesso em: 11 mar. 2019.

BASIC, D. et al. Short-and long-term effects of dietary Ltryptophan supplementation on the neuroendocrine stress response in seawater-reared Atlantic salmon (Salmo salar). Aquaculture, v. 388, p. 8-13, 2013.

BOMFIM, M. A. D. et al. Níveis de lisina, com base no conceito de proteína ideal, em rações para alevinos de Tilápia-do-Nilo. Revista Brasileira de Zootecnia, v. 39, n. 1, p. 1-8, 2010.

BOSCOLO, W. R. et al. Nutrição de peixes nativos. Revista Brasileira de Zootecnia, v. 40, 2011. Suplemento especial.

CYRINO, J. E. P. et al. A piscicultura e o ambiente: o uso de alimentos ambientalmente corretos em piscicultura. Revista Brasileira de Zootecnia, v. 39, p. 68-87, 2010.

FARHAT; KHAN, M. A. Dietary L-tryptophan requirement of fingerling stinging catfish, Heteropneustes fossilis (Bloch). Aquaculture Research, v. 45, n. 7, p. 1224-1235, 2014.

FISHER, C.; MORRIS, T. R. The determination of the methionine requirement of laying pullets by a diet dilution technique. British Poultry Science, v. 11, n. 1, p. 67-82, 1970.

FURUYA, W. M. et al. Tabelas brasileiras para nutrição de tilápias. Toledo: GFM, 2010. 100 p.

FURUYA, W. M. et al. Exigência de lisina digestível para a tilápia do Nilo de 87 a $226 \mathrm{~g}$ alimentada com dietas balanceadas para a relação arginina:lisina. Semina: Ciências Agrárias, v. 34, n. 4, p. 1945-1954, 2013.

HOSSEINI, S. A.; HOSEINI, S. M. Effect of dietary tryptophan on stress response of wild common carp Cyprinus carpio L. World Journal Fish and Marine Sciences, v. 5, p. 49-55, 2013.
KRÓL, J.; ZAKĘŚ, Z. Effect of dietary L-tryptophan on cannibalism, survival and growth in pikeperch Sander lucioperca (L.) post-larvae. Aquaculture International, v. 24, n. 2, p. 441451, 2016.

LATINI, A. O. et al. (org.). Espécies exóticas invasoras de águas continentais no Brasil. Brasília: MMA, 2016. 791 p. (Série Biodiversidade, 39).

LEMME, A. Recomendaciones de aminoácidos para carpas comunes-Avances en métodos para modelar. AMINO News, v. 17, n. 1, p. 15-27, 2013.

MENDONÇA, P. P. et al. Influência do fotoperíodo no desenvolvimento de juvenis de tambaqui Colossoma macropomum. Arquivos de Zootecnia, v. 58, n. 223, 2009.

NATIONAL RESEARCH COUNCIL. Nutrient requirements of fish and shrimp. Washington: National Academy Press, $2011.360 \mathrm{p}$.

NGUYEN, L. et al. Tryptophan requirement in semipurified diets of juvenile Nile tilapia Oreochromis niloticus. Aquaculture, v. 502, p. 258-267, 2019.

PEZZATO, L. E.; BARROS, M. M.; FURUYA, W. M. Valor nutritivo dos alimentos utilizados na formulação de rações para peixes tropicais. Revista Brasileira de Zootecnia, p. 43-51, 2009.

PIANESSO, D. et al. Determination of tryptophan requirements for juvenile silver catfish (Rhamdia quelen) and its effects on growth performance, plasma and hepatic metabolites and digestive enzymes activity. Animal Feed Science and Technology, v. 210, p. 172-183, 2015.

RODRIGUES, A. P. O. Nutrição e alimentação do tambaqui (Colossoma macropomum). Boletim do Instituto de Pesca, v. 40, n. 1, p. 135-145, 2014.

ROSSI, L.; TIRAPEGUI, J. Implicações do sistema serotoninérgico no exercício físico. Arquivos Brasileiros de Endocrinologia, v. 48, n. 2, p. 227-233, 2004.

ROSTAGNO, R. S. et al. Tabelas brasileiras para aves e suínos: composição de alimentos e exigências nutricionais. 2 . ed. Viçosa: Universidade Federal de Viçosa, 2011. 141 p.

SOUSA, T. J. R. et al. Phosphorus requirements of tambaqui juveniles. Semina: Ciências Agrárias, v. 39, n. 5, p. 2145-2156, 2018.

SILVA, D. J.; QUEIROZ, A. C. Análise de alimentos: métodos químicos e biológicos. 3. ed. Viçosa: Universidade Federal de Viçosa, 2005. $235 \mathrm{p}$.

SILVA, J. C. et al. Lysine requirement for tambaqui juveniles. Semina: Ciências Agrárias, v. 39, n. 5, p. 2157-2168, 2018.

SIQUEIRA, J. C. et al. Modelos matemáticos para estimar as exigências de lisina digestível para aves de corte ISA Label. Revista Brasileira de Zootecnia, v. 38, n. 9, p. 1732-1737, 2009.

TAKISHITA, S. S. et al. Níveis de lisina digestível em rações para alevinos de tilápia-do-Nilo. Revista Brasileira de Zootecnia, v. 38, n. 11, p. 2099-2105, 2009. 
UNIVERSIDADE FEDERAL DE VIÇOSA. SAEG: Sistema para análises estatísticas. Versão 9.1. Viçosa, MG: Fundação Arthur Bernardes, 2007.

ZAMINHAN, M. et al. Dietary tryptophan requirements of juvenile Nile tilapia fed corn-soybean meal-based diets. Animal Feed Science and Technology, v. 227, p. 62-67, 2017.
ZAMINHAN, M. et al. Total and available tryptophan requirement of Nile tilapia, Oreochromis niloticus, fingerlings. Aquaculture Nutrition, v. 24, n. 5, p. 1553-1562, 2018.

ZEHRA, S.; KHAN, M. A. Dietary tryptophan requirement of fingerling Catla catla (Hamilton) based on growth, protein gain, RNA/DNA ratio, haematological parameters and carcass composition. Aquaculture Nutrition, v. 20, 2014.

(C) $\odot$ This is an open-access article distributed under the terms of the Creative Commons Attribution License 